\title{
PROFESSIONAL COMPETENCES OF MUSIC TEACHER: ATTITUDE OF STUDENTS
}

\author{
Jolanta Abramauskiene
}

Academy of Education, Vytautas Magnus University, Lithuania

\begin{abstract}
The importance of the teacher's role in society is predetermined by developing and everincreasing advances in science, technology and social relations, which also create new demands for young people and adults. This article analyses expectations of students (pre-service music teachers) about the competences of a contemporary music teacher. The concept of the professional music teacher is revealed and validated; successful professional activities of music teachers are also highlighted. The data of the qualitative research (content analysis) related to the music teacher's personal traits, general pedagogical and subject-specific competences are introduced. It has been revealed that scholarly music teachers have certain traits, which reveal themselves through the teacher's professionalism, competence, personal qualities and values.
\end{abstract}

Keywords: music teacher's competences, subject-specific competence, musical education, student's attitude.

\section{Introduction}

In contemporary society it is crucial for teachers to understand that the school and learners are undergoing changes. Therefore the teacher cannot stay aside and has to find time for self-education and self-development in order to not stay behind innovation (Fuller \& Bown, 1975; Zhu, et. al. 2013). Thus, teachers' readiness to work under new conditions gains importance. The assessment carried out by the European Commission (2016) showed that Lithuania does not adequately develop the skills important for a young person. Although the level of education has improved, some students do not have sufficient skills. It is recommended to pay closer attention to learners' cognition, substantiation of educational practice on research, work organization, situation analysis, leadership and teamwork applying the project and research methods. Increasing the professionalism of teachers is a strategic goal of education in Lithuania. The aim of the State Education Strategy for 2013-2022 (2012) is to achieve establishment of a professional, continuously developing and efficient pedagogical community. To ensure the growth of teachers' professionalism in the future, it is important for all teachers to be equipped with strong professional competences (Selvi, 2010). However, the decreasing authority of the school and the teacher is more often perceived as the cause of teachers' professional problems and the result of inappropriate teacher competence (Nedzinskaite \& Barkauskaite, 2017). Teacher competences are closely related to their suitability for pedagogical activities. K. Gupta (1999) states that competence is knowledge, skills, attitudes or behavior patterns that enable one to perform the activities of a given occupation or to function to the standards expected in employment. Studies conducted by researchers show that, while discussing a contemporary teacher, students highlight professional pedagogical competence, which is revealed through the teacher's intention to teach students to learn, to professionally present the content of education, to use different teaching methods that stimulate the activity of students, to differentiate educational content and to manage the educational process (Galkienè, 2011). Therefore, an individual, who seeks to become a teacher, must manage his or her life according to the requirements for the profession of a teacher, which inevitably requires certain personal qualities as well as skills necessary for a teacher, practical skills and fundamental knowledge that every teacher that is willing to work with learners should have. Requirements for the competence of Lithuanian teachers are defined in detail in the Description of the Teacher's Professional Competences (2007). Thus, a changing approach to the educational process promotes changes and raises new requirements for the teacher: to take up other unusual roles, to reflect and to develop the existing competences and to acquire new ones. M. Binkley, et al. (2010) have divided the 21 st century skills into the categories: ways of thinking (creativity/innovation, critical thinking, problem solving, decision-making, learning to learn); ways of working (communication, collaboration); tools for 
working (information literacy, ICT literacy); living in the world (citizenship, life and career, personal and social responsibility - including cultural awareness and competence). These 21 st century skills are defined as crossdisciplinary ones and are relevant to many aspects of contemporary life in a complex world. It is not enough for a contemporary teacher to be just a good specialist in his or her subject and to possess pedagogical knowledge and abilities (Korthagen, 2004; Grahn \& Öfverström, 2009; Bates, 2011). Openness to innovation, autonomy, flexibility, creativity, collaborative skills, critical thinking and ability to make mature professional development decisions are equally necessary (Goodson \& Hargreaves, 1996; Reagan, 2010). Consequently, discussing teachers' competences in order to improve the educational process at school is of utmost importance.

\section{Statement of the Problem}

The significance of teacher's professionalism, competences and personality traits for the quality of education has always been an important target of scientific interests. The purpose of this study is to reveal the reflection of this problem in terms of the attitude expressed by current students. The competences of music teachers coupled with personal qualities as well as with general, pedagogical and subject-specific teacher competences, form the basis for achieving the highest proficiency of the music teacher.

\section{Purpose of the Study}

The purpose of study is to identify the important qualities and competences of contemporary music teachers from the perspective of students.

\section{Music Teacher's Professional Competence: Review of Literature}

Contemporary musical education is perceived as a process that integrates creation, creative ideas and their practical implementation, develops musical skills, values and understanding of music. According to Z Rinkevičius (2005), performing the role of the creator and with the help of expressiveness, a music teacher is able to instil experienced emotional values to the classroom. A music teacher, being a creative personality, is able to present his or her subject in an original and distinctive way, communicating with students, encouraging their artistic taste and creative thinking. Musical education is part of learners' general education. It is particularly important providing each student with the basics of cultural awareness and musical competence, developing an emotional and creative personality, who is willing and able to participate in musical life in various forms (Lithuanian Primary and General Education Framework, 2008). However, musical education in school practice is still perceived traditionally, without proper consideration of the dynamics of society's development and qualitatively new competences. According to M. L. Mark, \& P. Madura (2010), G. Gapšyte \& N. Bankauskiene, (2016), the problem of the competence of general education music teachers is very important and it is necessary to look for ways and means to improve these competences. S. Kauffeld (2006) states that the competences can be subdivided into four main categories: professional competences (e.g. knowledge of processes), methodological competences (e.g. techniques to structure yourself), social competences (e.g. socially appropriate behaviour in interactions) and personal competences (e.g. strategies to handle yourself, e.g. selfreflection). According to the author, the results show that hypotheses are fully supported for methodological competence, partially supported for professional and self-competence and not supported for social competence. Furthermore, the profession of music teacher includes many areas in which one can present himself or herself not only as a music teacher but also as an artist. J. Lasauskienè (2010), for example, distinguishes the functions of the music teacher's professional activity: he or she is able to organize the lesson's activities, to prepare and organize the events of organization or community, commemorative and thematic concerts, musical projects, to organize non-formal education, to lead orchestras, choirs, vocal and instrumental ensembles and soloists. When discussing the expression of the competences of the general education music teacher, H. Šečkuviene (2008) notes that the music teacher must have good knowledge of the systemic fundamentals of special musical 
subjects, teacher's professional musical expression is very important, the teacher himself or herself should participate in some performing activities, constantly accumulate, update his or her musical aesthetic experiences and be able to convey these values to the learners. Similarly, E. Balčytis (2008) emphasizes that the teacher of music must be able to play piano and other instruments, have well-developed musical, vocal hearing and voice, lead choirs, instrumental and vocal ensembles, orchestras, know how to conduct orchestras and to educate soloists, be able to plan and deliver music lessons at different stages of education, be well aware of music education programmes, educational systems, textbooks and other educational aids, understand and apply modern technologies and perceive ethno culture, etc. Being a professional music teacher demands more than just musical skills and understandings (formal and/or informal) or having practical savvy and experience. These abilities and qualities are necessary but not sufficient for teaching music thoughtfully, wisely, effectively and compassionately (Elliott, 2012). It can be noted that the profession of music teacher is broad and multifaceted and very important in today's education, because it enhances the children's artistic taste to music, develops the perception of the music world, and introduces spiritual, artistic, musical and cultural values.

The professional competences of music teachers have also been studied by J. Abramauskienè (2002), M. J. Bergee \& S. M. Demorest (2003), J. Eros (2013), Koca (2017) and other scholars. The works of these authors mostly emphasize the teacher's subject competence, while other scholars (Isbell, 2008, Begić, et al., 2017) focus on the importance of the personalities of the teacher pedagogical, psychological qualities and socialization for the successful work of the music teacher. These are key factors in aiming to distinguish the competences of a contemporary music teacher.

\section{Organization of the Study}

\section{Research Instrument and Methodology}

The study was conducted in 2017 using a written surveying method with an open-ended questionnaire. The questionnaire focused on the presentation of the aspects of the music teacher's professional competences. The methods of scientific literature analysis and qualitative research were applied. The content of the answers to open-ended questions was analysed applying the method of qualitative data (content) analysis. J. V. Anfara \& $\mathrm{K}$. Brown, et al. (2002) notes that the content analysis is a valid method of qualitative diagnostics, which allows making specific conclusions based on the analysed text. It can be stated that the text presented by the student is the material of the content analysis as an educational diagnostic study and reflects the process of personal reflection, which is an essential aspect of experiential learning (Creswell, 2009). A model specific to qualitative research is followed: presenting genuine statements of participants of the study, codifying all the information into categories and subcategories, interpreting it in terms of the attitude of the respondents towards the profession of music teacher and identifying the personal qualities and traits, general teacher and subject competences that should be acquired by a good music teacher. Having applied the methodological concept of qualitative diagnostics (Mayring, 2000), the obtained results allow to determine the specific features of the context in which the participant operates, and, on this basis, to anticipate the change of activity and the needs of development of competences.

\section{Participants}

In total the study involved 44 3rd-4th year students of music education at Lithuanian University of Educational Sciences, who took part in the research after their teaching practice. Such students are already able to partially evaluate attitudes and music teachers' competences. The majority of the respondents were females $(85.2 \%)$ and the average age of the respondents totaled 21 years. The research sample was compiled by means of targeted screening. 


\section{Research Ethics}

All students agreed to participate in the survey on voluntary basis. The confidentiality was kept during the research. The research topic, problem, purpose and nature were presented to the participants of the study. The consent of the participants was obtained and the aspect of free decision-making was considered, that is, the respondent's ability to refuse to participate in the survey.

\section{Results \& Discussion}

The students' answers were analysed while evaluating their attitude towards the teacher, who appeals to them. Taking into account the content of proving statements, four components have been distinguished: 1) personal qualities of a music teacher; 2) general pedagogical competence; 3) subject competence; 4) teachers' traits unattractive to students. On the basis of the results of the conducted study, D. Strakšienè (2004) emphasizes the importance of the teacher's personality type to the quality of teaching organization: it is argued that those teachers whose professional types are based on favourable professional approaches courageously use various forms of organization of learning, complementary means and demonstrate their abilities in the teaching process. On the other hand, teachers who do not trust their professional skills often negatively assess the cognitiveemotional tone of the lesson, poorly evaluate the learners' discipline in particular, avoid using a wider variety of teaching aids and demonstrating their skills. Therefore, it is important to identify what qualities a contemporary music teacher should have.

Personal qualities of a music teacher deserve a special attention when it comes to the picture of a professional music teacher, who is cohesively leading the educational process for the learners. The general cultural competence is reflected in the teacher's personal qualities and his or her attitude to work. It is important to take a closer look at the insights made by the students (Table 1).

Table 1: Students' attitude towards personal features of a music teacher

\begin{tabular}{|c|c|c|}
\hline Category & Subcategory & Statements \\
\hline \multirow{10}{*}{$\begin{array}{l}\text { Personal } \\
\text { qualities of } \\
\text { music } \\
\text { teacher }\end{array}$} & $\begin{array}{l}\text { Communicabil } \\
\text { ity }\end{array}$ & $\begin{array}{l}\text { "communicative"; "ability to communicate"; "communicate with learners"; } \\
\text { "good at cooperation"; "effective communication". }\end{array}$ \\
\hline & $\begin{array}{l}\text { Love for the } \\
\text { learners }\end{array}$ & $\begin{array}{l}\text { "loving learners"; "love students"; "love for each student"; "love their } \\
\text { students"; "love the work". }\end{array}$ \\
\hline & Responsibility & $\begin{array}{l}\text { "responsible", "sense of responsibility"; "responsibilities"; "respect"; } \\
\text { "responsibility". }\end{array}$ \\
\hline & Creativity & "creative"; "imagination and creative"; "originality"; "with imagination". \\
\hline & $\begin{array}{l}\text { Sense of } \\
\text { humour }\end{array}$ & "humorous"; "humorous language"; "having a sense of humour". \\
\hline & Friendliness & "friendly"; "friendliness"; "friendly with students". \\
\hline & Sincerity & "sincerity"; "sincerity"; "sincerity". \\
\hline & Honesty & "honest"; "honesty"; "conscience"; "conscience". \\
\hline & Patience & "patience"; "patience". \\
\hline & Others & $\begin{array}{l}\text { "organized"; "with personality charm"; "must have lofty morality"; } \\
\text { "excellent morals"; "self-confidence"; "self - regulation"; "ambition"; "nice } \\
\text { looking"; "like the sunshine in the school"; "positive emotions". }\end{array}$ \\
\hline
\end{tabular}

Most of the students are inspired by communicative, responsible, creative, friendly, sincere, honest and patient teachers, who love their learners and have a sense of humour. They disclose the personality of the teacher not only through his or her social perception ("communicative", "loving learners"; "understanding learners"; "having a sense of humour"; "creative"; "organized"; "with personality charm"; "of excellent morals"; "self- 
confidence" and "positive emotions"), but also through his or her personality traits ("responsibility"; "friendliness"; "sincerity"; "honesty" and "patience").

Music teacher's general pedagogic competence discloses the teacher's image through professional education. This competence is reflected in the 7 sub-categories identified after the content analysis (Table 2): good subjectspecific knowledge, innovation ability, lifelong learning ability, knowledge of how to make others interested, ability to find common language with learners, respect for and understanding of them and being strict but fair. Most of the students like teachers who are skilled and knowledgeable in their subject and this is illustrated by the following statements: "ability to organize teaching"; "best professional knowledge, management experience and teaching experience"; "understanding of each student's learning situation"; "good language expression ability"; "ability to understand the students of different ages"; "ability to study and organize teaching materials". The innovation ability is justified by the students' thoughts: "ability to use modern information technology"; "ability to apply modern multimedia technologies"; "continuous improvement in teaching innovation"; "high ability to innovate"; "able to adapt to modern education". The ability of the teacher to evoke interest is grounded on the following thoughts of students: "ability to tell in an interesting manner"; "have a lot of motivation to teach"; "inspire with his or her work"; "motivation for learning and teaching"; "make the knowledge more interesting, more fun"; "let the children give full play to their imagination and creative space". Students are also fascinated by music teachers who "maintain good relationships with learners"; "always help or understand"; "are able to assess learners according to their knowledge and not relying on personal sympathy", "care for learners"; "and understand learners". It is interesting that students care if a music teacher is "strict but fair"; "able to control learners" and "supports discipline". According to the opinion of the scholars (Sonmark et al., 2017), the abilities to communicate and collaborate with learners, their parents, colleagues, to be aware of own needs and values and to find the appropriate means for their implementation are the most significant ones among the signs disclosing general pedagogical competence .

Table 2: Students' attitude towards music teacher's general pedagogic competence

\begin{tabular}{|c|c|c|}
\hline Category & Subcategory & Statements \\
\hline \multirow[t]{3}{*}{$\begin{array}{l}\text { Music teacher's } \\
\text { professional } \\
\text { competences }\end{array}$} & $\begin{array}{l}\text { Good subject- } \\
\text { specific } \\
\text { knowledge }\end{array}$ & $\begin{array}{l}\text { "ability to organize teaching"; "organizing ability of extracurricular } \\
\text { activities"; "professional knowledge and teaching theoretical basis"; } \\
\text { "should have best professional knowledge, management experience } \\
\text { and teaching experience"; "understanding of each student's learning } \\
\text { situation"; "a brilliant man of wide learning"; "good language } \\
\text { expression ability"; "ability to understand the students of different } \\
\text { ages"; "ability to study and organize teaching materials"; "the } \\
\text { application ability of various teaching methods"; "determine the } \\
\text { teaching objectives, developing and utilizing educational resources, } \\
\text { ability to write teaching plans, analysis and organization of teaching } \\
\text { materials, interpersonal skills, ability to organize and manage"; "can } \\
\text { improve the interest of teaching and the learning efficiency of } \\
\text { students". }\end{array}$ \\
\hline & Innovation ability & $\begin{array}{l}\text { "ability to use modern information technology"; "ability to skilfully } \\
\text { use network information technology"; "ability to apply modern } \\
\text { multimedia technologies"; "continuous improvement in teaching } \\
\text { innovation"; "advanced multimedia teaching program"; "high ability } \\
\text { to innovate"; "grasp of the modern multimedia technology"; "ability } \\
\text { to adapt to modern education". }\end{array}$ \\
\hline & $\begin{array}{l}\text { Lifelong learning } \\
\text { ability }\end{array}$ & $\begin{array}{l}\text { "ability to learn lifelong, to sift the old, to activate the new knowledge } \\
\text { and to accumulate knowledge"; "desire to improve the professional } \\
\text { level, striving to be a qualified teacher"; "keeping pace with the times } \\
\text { and constant update of our knowledge"; "constant improvement of }\end{array}$ \\
\hline
\end{tabular}




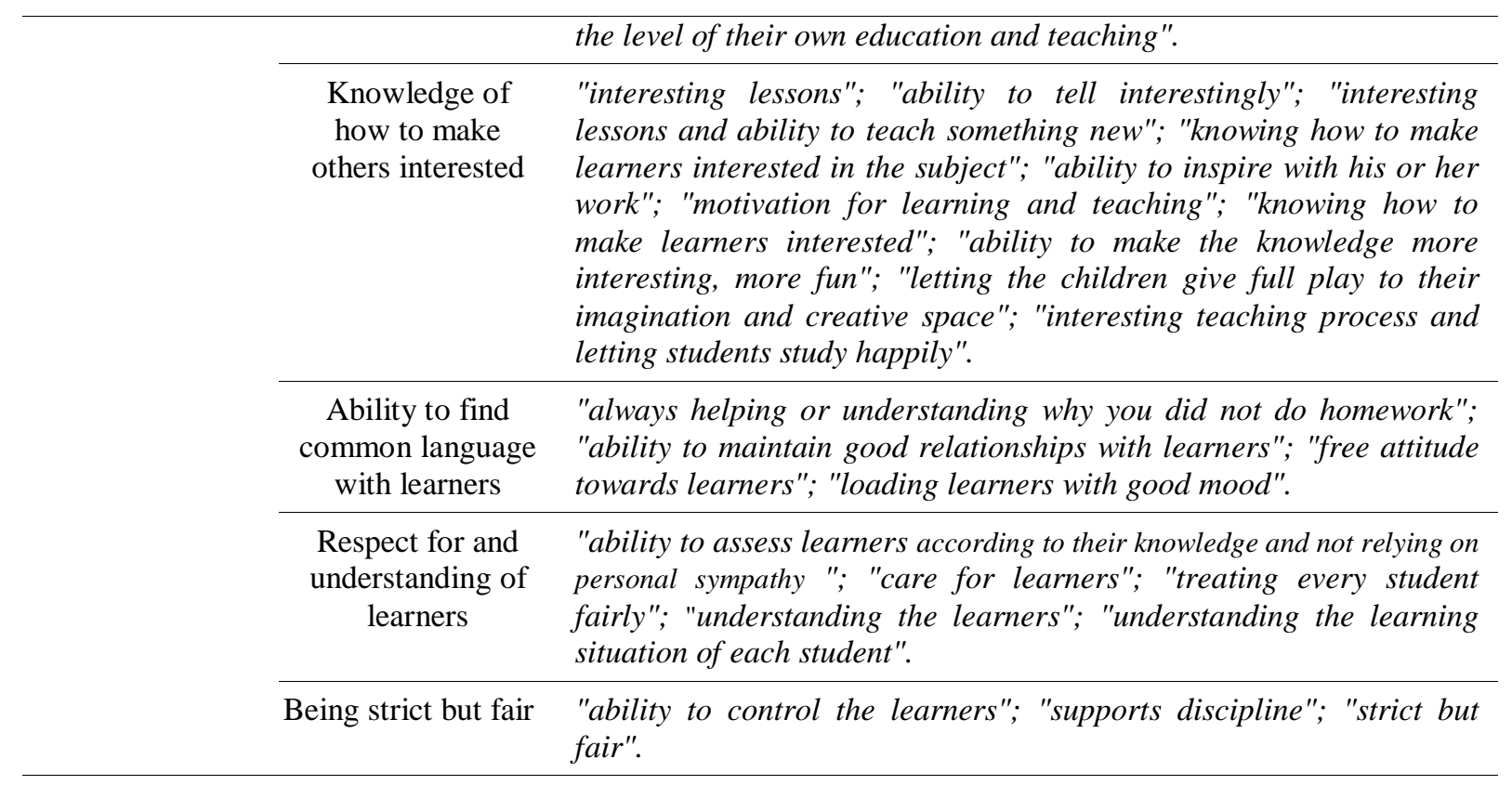

Music teacher's subject competence, which includes the teacher's preparation in terms of the subject, is another significant area for evaluating the teacher as a professional.

Table 3: Students' attitude towards music teacher's subject competences

Category Subcategory Statements

Music teacher's subject-specific competences
Musical skills

Knowledge music "the skills of music professional technical level"; "excellent singing talent"; "expression ability"; "good skill of singing"; "basics of music theory, preliminary composing techniques, solfeggio, singing skills, ability of chorus and orchestra conductor, keyboard instrument"; "music analysis and music history"; "good playing level, playing skills, excellent classroom teaching ability"; "advanced teaching ideas, unique teaching style"; "good performance ability, ability to play instruments, good sense of music, good self-image"; "teaching ability, music classroom teaching is the core of music education work"; "good skills of playing musical instruments, expressive singing skills, some creative skills"; "give many interesting presentations"; "ability to perform on musical instruments, singing skills"; "able to play accompaniment". of "interested in innovations, knowing the kinds of music, different genres"; "aware of interesting things about music"; "good knowledge of music education theory"; "professional music literacy"; "music classroom teaching"; "theoretical knowledge of music".
Attitudes and

approaches "stimulating students' interest in music, inspiring students' creativity and ideas"; "inspired to create"; "a good aesthetic attitude"; "comprehensive musician"; "correct guidance of students, in love with music"; "guidance of beauty and emotion"; "ability to answer various musical questions". 
This competence is illustrated through the subcategory distinguished applying the content analysis: welldeveloped musical skills, music knowledge, attitudes and approaches (Table 3). Though it is proven by fewer probative statements, it is obvious that students focus on general professional education of teachers as specialists in the taught subject. Students are first of all inspired by teachers with good musical skills: "excellent singing talent”, "expression ability”; "basics of music theory, preliminary composing techniques, solfeggio, singing skills, ability of chorus and orchestra conductor, keyboard instrument"; "ability to perform on musical instruments, singing skills, have some creative skills"; “ability to play accompaniment”. The teachers' music knowledge is important as well: "interested in innovations, knowing the kinds of music, different genres"; "aware of interesting things about music"; "theoretical knowledge of music". Meanwhile, the following is stated about the teacher's attitudes and approaches: "stimulating students' interest in music, inspiring students' creativity and ideas"; "a good aesthetic attitude"; "guidance of beauty and emotion"; "loving music and learners". Students frequently identify the teacher's subject-specific preparation with the general teacher's education, his or her erudition. The music teacher's versatility is important to the students: "well-rounded musician"; "inspired to create" and "able to answer various music-related questions".

Unattractive qualities of a music teacher are disclosed by 4 subcategories (Table 4): emotional factors, vocational skills, attitudes towards learners and others. The provided statements suggest what kind of teachers are not liked by the respondents: "emotional, likes to read morals for nothing or for our personal opinions"; "often offends by meaningless comment"; "without any emotions and feelings"; "boring music teachers without patience in class"; "teacher who does not understand humour"; "feeling superior to others, displaying power"; "the teacher who is not strict with his students" and "without patience". Eight respondents have claimed that a music teacher does not have any qualities they do not like. Although the students' considerations about the unattractive qualities of a teacher are detected much less often, the very fact that they notice teacher's mood, shows the learner's sensitivity to the teacher's personality.

Table 4. Unattractive qualities of music teacher

\begin{tabular}{lll}
\hline Category & \multicolumn{1}{c}{ Subcategory } & \multicolumn{1}{c}{ Statements } \\
\hline & Emotional factors & "emotional, likes to read morals for nothing or for our \\
personal opinions"; "too much sensitivity"; "often offends by \\
meaningless comments"; "without any emotions and feelings"; \\
"too serious with students"; "boring music teachers without \\
patience in class"; "teacher who does not understand \\
humour".
\end{tabular}

Summing up the research results, it can be stated that students have not forgotten that the teacher first of all is a human being and have taken into consideration both personal and pedagogical qualities of their teachers. For the students, the teacher is primarily a "senior friend" with knowledge of the subject. They expect not only 
scientific knowledge, but also lifelong advice, support and help with solutions to both scientific and personal problems. S. G. Nielsen and I. A. Westby (2012) argue that it is important to maintain a broad and open view, both in the development of professional music teachers and in what it means to be a professional.

\section{Conclusions}

The analysis of scientific literature showed that the competence of a music teacher embraces the teacher's knowledge, skills, abilities, values, attitudes and other personal qualities necessary for successful educational activity. It is a broad and multifaceted concept but very important in today's education as it enhances children's artistic taste to music, contributes to development of their perception of the music world and introduces spiritual, artistic, musical and cultural values.

The learners' answers about the contemporary music teacher allowed to distinguish four components: personal teacher's qualities, general pedagogical competences, subject-specific competences and unattractive qualities of teachers. Most of the students are inspired by communicative, loving, responsible and creative music teachers, who have a sense of humour, are friendly, sincere, honest and patient. The analysis of their answers revealed that the students notice a lot of delicate qualities of teachers. They disclose the teacher's personality not only through its social perception but also through his or her personal sense of these qualities. According to the students, to be the teacher of higher professional competence means having a good awareness of the subject, knowing how to make others interested, finding common language with learners, knowing ICT, respecting and understanding their learners and being strict but fair. While composing the picture of contemporary music teacher, the respondents distinguish the subject competence, which they highlight not only as perfect subjectspecific preparedness of teachers but also focus on their general education and erudition. The students tend to remember that the teacher is a human being first of all and they value all his or her qualities: personal and pedagogical ones.

\section{Acknowledgements}

The research reported in this article was made possible by grants from the Research Council of Lithuania and European Union structural funds. I thank to my students who took part in the interviews, colleagues who assisted me, Music Department and Lithuanian University of Educational Sciences.

\section{References}

Abramauskienė, J., 2002, Peculiarities of Primary School Teachers' Musical Competence, Pedagogy, 70, 9-12.

Anfara, J., V., A., Brown, K., Mangione, T., 2002, Qualitative Analysis on Stage: Making the Research Process More Public, Educational Researcher, 31(7), 28-38.

Balčytis, E., 2008, On the Significance, Aims, Objectives and Possibilities of Music Education at School, Kürybos erdvès, 9, 15-25.

Bates, V. C., 2011, Preparing Rural Music Teachers: Reflecting on "Shared Vision". Journal of Music Teacher Education, 20, 89-98.

Begić, J. Š., Begic A. \& Škojo T., 2017, Opinions of University Music Teachers on the Musical Competencies

Bergee, M. J., \& Demorest, S. M., 2003, Developing Tomorrow's Music Teachers Today, Music Educators Journal, 89 (4), 17-20.

Binkley M., Erstad O., Herman J., Raizen S., Ripley, M Rumble, M., 2012, Defining 21st century skills. In Griffin, P., McGaw, B., Care, E. (eds.), Assessment and Teaching of 21st Century Skills, Netherlands: Springer, $17-66$.

Creswell, J. W., 2009, Research Design: Qualitative, Quantitative, and Mixed Methods Approaches, Los Angeles: Sage Publications. 
Description of Professional Competences of Teachers, Approved by Order of the Minister of Education and Science of the Republic of Lithuania, No. ISAK-54 of 15 January 2007, Official Gazette, 2010, 12-511.

Elliott, D., 2012, Music Education Philosophy. In McPherson G. E \& Welch G. F. (eds.), The Oxford Handbook of Music Education, 1, Oxford: Oxford University Press, 10-35.

Eros, J., 2013, Second-Stage Music Teachers' Perceptions of the Professional Development, Journal of Music Teacher Education, 20(2), 20-33.

European Commission's Recommendation about Lithuania's National Reform Programme of 2016, 2016, Brussels, Available online at: http://ec.europa.eu/europe2020/pdf/csr2016/csr2016_lithuania_lt.pdf (accessed 10 February 2018).

Fuller, F. \& Bown, O., 1975, Becoming a Teacher. In K. Ryan (eds.), Teacher Education (74th Yearbook of the National Society for the Study of Education, 2, 25-52, Chicago: University of Chicago Press.

Galkienè, A., 2011, Image of a Modern Teacher in Pupils’ Perception, Pedagogy, 101, 82-90.

Gapšyte, G., Bankauskienė, N., 2016, Music Teacher's Expression of Competencies, Social Education, 42 (1), 45-59.

Goodson, I. F., Hargreaves, A., 1996, Teachers’ Professional Lives, UK: Routledge Falmer Press.

Grahn, M. and Öfverström, C., 2009, Leadership Challenges in Music Education, Problems in Music Pedagogy, 5, 73-86.

Gupta, K., 1999, A Practical Guide for Need Assessment, San Francisco: John Wiley \& Sons.

Isbell, D. S., 2008, Musicians and Teachers: The Socialization and Occupational Identity of Preservice Music Teachers, Journal of Research in Music Education, 56 (2), 162-178.

Kauffeld, S., 2006, Self-directed Work Groups and Team Competence, Journal of Occupational and Organizational Psychology, 79 (1), 1-21.

Koca, S., 2017, Competencies of Music Teacher Candidates Taking Pedagogical Formation Training, International Online Journal of Educational Sciences, 9 (2), 370-380.

Korthagen, F. A. J., 2004, In Search of the Essence of a Good Teacher: Towards a More Holistic Approach in Teacher Education, Teaching and Teacher Education, 20(1), 77-97.

Lasauskienė, J., 2010, Music Teacher's Activities and Competencies, Vilnius: Publishing House of Vilnius Pedagogical University.

Lithuanian Primary and General Education Framework, Approved By the Minister of Education and Science of the Republic of Lithuania 26 August 2008, Resolution No. ISAK-2433.

Mark, M. L., Madura P., 2010, Music Education in Your Hands, New York: Routledge.

Mayring, Ph., 2000, Qualitative Content Analysis, Forum: Qualitative social Research, 2 (1), 1-10.

Nedzinskaitè, R. \& Barkauskaite, M., 2017, Abilities of Transformational Leadership Conditioning Teacher Professionalism: the Perspective of Teachers-Practitioners, Pedagogy, 125 (1), 37-56.

Nielsen, S. G., Westby, I. A., 2012, The Professional Development of Music Teachers. In Danielsen B. A. B., Johansen G. (eds.), Educating Music Teachers in the New Millennium, 141-155.

Reagan, T., 2010, The Professional Status of Teaching. In R. Bailey, R. Barrow, D. Carr, C. McCarthy (eds.), The Sage Handbook of Philosophy of Education, Los Angeles: Sage, 210-221.

Rinkevičius, Z., 2005, Muzikos pedagogika (Music Pedagogy), Klaipėda: University Press.

Šečkuvienè, H., 2008, Pasirengimas mokytojų rengimo pertvarkai: reikalavimai mokytojų stažuotojų globejjų mentorių atrankai (Preparing for the Teacher Training Reform: Requirements for Teacher Trainee's Tutor Mentor Selection). Tiltai, 37, 13-18.

Selvi, K., 2010, Teachers' Competencies. Cultural International Journal of Philosophy of Culture and Axiology, 7(1), 167-175.

Strakšienè, D., 2004, A Teacher's Personality Type - Precondition for Collaboration in Music Lesson, Pedagogy, 72, 143-150. 
The State Education Strategy for 2013-2022, 2012, Vilnius: Ministry of Education and Science of the Republic of Lithuania.

Zhu, C., Wang, D., Cai, Y. H. \& Engels, N., 2013, What Core Competencies are Related to Teachers' Innovative Teaching? Asia-Pacific Journal of Teacher Education, 41(1), 9-27. Available online at: http://dx.doi.org/10.1080/1359866X.2012.753984 (accessed 10 February 2018). 